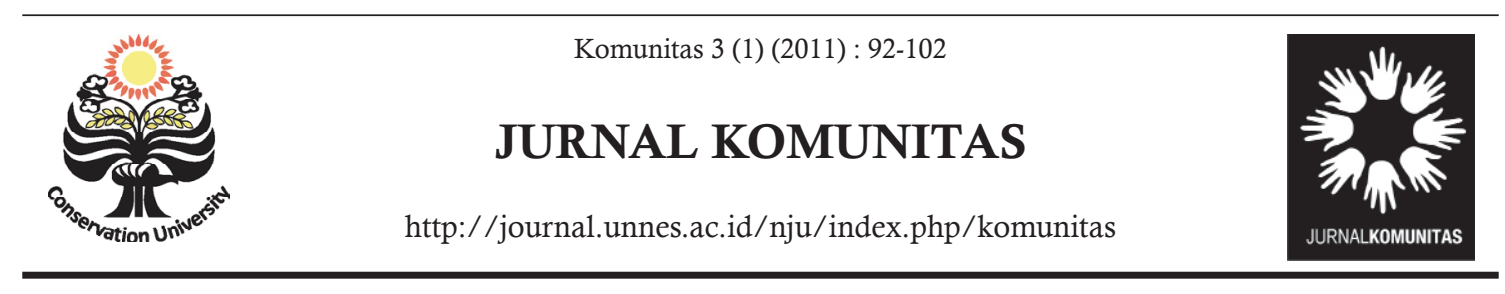

\title{
PEMBELAJARAN SOSIOLOGI YANG MENGGUGAH MINAT SISWA
}

\section{Hezti Insriani}

SMA Kristen Tri Tunggal Semarang Jawa Tengah Indonesia

\section{Info Artikel}

Sejarah Artikel:

Diterima Desember 2010

Disetujui Januari 2011

Dipublikasikan Maret 2011

Keywords:

sociology teaching; innovative approach; students' interest.

\begin{abstract}
Abstrak
Mata pelajaran Sosiologi dipandang oleh sejumlah siswa sebagai mata pelajaran yang membosankan. Muatan materi sosiologi yang menyajikan banyak teori dan konsep seperti mengandung konsekuensi kepada siswa untuk menuntut semuanya dihafal secara baik. Model pembelajaran yang membosankan semakin membuat mata pelajaran ini kurang diminati oleh siswa. Strategi inovatif sudah dilakukan, namun pada prakteknya operasionalisasi model pembelajaran itu kurang efektif sehingga guru banyak yang kembali menggunakan model pembelajaran konvensional. Artikel ini ditulis untuk menyampaikan model pembelajaran Sosiologi bagi siswa Sekolah Menengah Atas (SMA) berdasarkan pengalaman saya mengajar. Menurut pengalaman saya, strategi yang bisa digunakan untuk mengatasi masalah pembelajaran sosiologi antara lain adalah mengajukan pertanyaan kritis, eksplorasi artikel dan gambar/foto, nonton film, penelitian sederhana, dan membuat catatan harian. Melalui startegi ini, pembelajaran yang bersifat konstruktivisme lebih mudah dioperasional. Cara ini lebih dapat memberikan kesempatan kepada siswa untuk membangun pembelajaran secara mandiri dan menjadikan siswa lebih dekat memahami kenyataan sosial sebagai bagian dari kehidupannya sekaligus sebagai materi pembelajaran sosiologi.
\end{abstract}

\begin{abstract}
Students often regard Sociology as a boring subject. The subject presents many sociological theories and concepts students to memorize. Boring method of teaching further makes the course less attractive to students. Innovative strategy have been used, but in practice the method is not effective and teachers return to conventional models. This article is written based on the author's experience in teaching Sociology among high school students. Based on my experience, strategies that can be used to create innovative learning include asking critical questions, exploring articles and pictures / photos, analyzing movies, doing simple research, and keeping a diary. Through this strategy, constructivist learning is much easier to run. This method is better able to provide the opportunity for students to develop independent learning and make students more intensively to understand social reality as a part of his life as well as the learning materials of sociology.
\end{abstract}

(C) 2011 Universitas Negeri Semarang

\footnotetext{
Alamat korespondensi:

SMA Kristen Tri Tunggal

Semarang Jawa Tengah Indonesia 50146
}

ISSN 2086-5465

E-mail: insrianihezti@yahoo.com 


\section{PENDAHULUAN}

Pelajaran Sosiologi adalah pelajaran yang telah dipelajari oleh siswa Sekolah Menengah Atas (SMA) sejak mereka duduk di bangku kelas X SMA. Lebih lanjut, pelajaran tersebut akan dipelajari lagi oleh siswa yang melanjutkan di kelas Ilmu Sosial atau program IPS. Sementara mereka yang melanjutkan di kelas Ilmu Alam atau program IPA tidak lagi mempelajari pelajaran ini. Sehingga, pelajaran Sosiologi ini disebut sebagai mata pelajaran khusus bagi siswa jurusan Ilmu Sosial.

Mengajar mata pelajaran Sosiologi untuk siswa SMA kelas Ilmu Sosial merupakan bukan hal yang mudah. Substansi materi yang begitu banyak dengan konsep dan teori tdak mudah untuk diajarkan oleh guru yang tidak memiliki latar belakang pendidikan sosiologi maupun sosiologi murni. Namun demikian masih banyak guru-guru yang tidak memiliki latar belakang keilmuan pendidikan sosiologi ataupun sosiologi murni mengajar mata pelajaran Sosiologi.

Hal yang sama berlaku pada mata pelajaran Antropologi, hasil penelitian Rochana (2010) menjelaskan bahwa mata pelajaran Antropologi diajarkan oleh sembarang guru dengan latar belakang pendidikan beragam. Sehingga menjadi hal yang biasa jika mata pelajaran Antropologi diampu oleh guru yang mempunyai latar belakang pendidikan PKK, Olah Raga, Seni dan BK. Selain aspek keilmuan, hal lain yang menjadikan mengajar mata pelajaran Sosiologi sebagai sebuah tantangan adalah karakter peserta didiknya.

Sejalan dengan hasil penelitian Rochana, mata pelajaran sosiologi juga dianggap sebagai mata pelajaran yang bisa diampu oleh sembarang guru. Akibatnya guru banyak menjelaskan konsep sosiologi secara keliru. Disamping itu materi sosiologi lebih banyak dijelaskan secara teks book. Guru kurang dapat mengembangkan konsep maupun teori sosiologi dengan konteks sosial kehidupan siswa.

Selain persolan latar belakang keilmuan guru pengampu mata pelajaran sosiologi, tantangan lain yang dihadapi guru selama mengajar mata pelajaran Sosiologi adalah terkait dengan siswa. Umumnya siswa SMA adalah anak-anak dengan energi yang cukup besar. Mereka tidak seperti anak-anak SD maupun SMP yang lebih cenderung bersifat konformis. Siswa-siswa SMA yang sedang dalam masa mencari jati diri agar sampai pada proses pendewasaan cenderung lebih reaksioner. Daya kritis dan sikap idealism mereka mulai muncul, karenanya guru tidak bisa memperlakukan mereka sebagaimana anak-anak SD maupun SMP. Oleh karena itu, diperlukan sebuah seni tersendiri dalam mengolah pembelajaran bagi anak-anak tersebut untuk menyalurkan kreatifitas mereka, khususnya dalam pembelajaran Sosiologi.

Tulisan berikut ini merupakan penjabaran apa yang telah menjadi pengalaman penulisdalam menjadi Guru Sosiologi di sebuah Sekolah Menengah Atas di Semarang. Pengalaman-pengalaman tersebut kemudian dituliskan agar kemudian dapat menjadi sebuah catatan. Semoga lewat tulisan ini dapat kita petik sebuah perenungan dan lalu melakukan sebuah inovasi baru dalam mengemas pembelajaran Sosiologi yang menggugah minat siswa.

Kita semua tentu sangat mengerti bahwa kelas adalah tempat semua siswa memperoleh pembelajaran. Dari situlah semua guru mata pelajaran berinteraksi dengan muridmuridnya untuk melakukan pembelajaran bersama. Hal ini pun berlaku untuk pelajaran Sosiologi. Pembelajaran Sosiologi dimulai dari kelas ketika guru menyampaikan materi pelajaran dan siswa melakukan aktivitas belajar. Berangkat dari pengertian tersebut, guru kemudian berjuang untuk memberikan pelajaran demi pelajaran dengan semenarik mungkin. Upaya ini dilakukan demi terpenuhinya misi yang dilakukan masing-masing guru, dan terwujudnya harapan mereka atas siswa mereka.

Demikian pula dalam kelas Ilmu Sosial, khususnya dalam pelajaran Sosiologi, guru berupaya sedemikian rupa agar pembelajaran yang berkaitan dengan masyarakat tidak hanya bersifat monoton sebagaimana tradisi pembelajaran klasik yang berorientasi pada ceramah guru. Guru sesunguhnya mengetahui situasi yang akan terjadi dengan pembelajaran sosiologi yang keseluruhan 
materinya merupakan konsep-konsep tentang masyarakat yang agaknya sulit diajarkan tanpa melalui kegiatan ceramah. Selain itu pembelajaran yang disampaikan melalui ceramah biasanya akan lewat begitu saja dari ingatan siswa, apalagi materi yang disampaikan dianggap kurang menarik di mata siswa. Namun lebih dari itu guru Sosiologi tentu memiliki sebuah tanggung jawab untuk memberikan pengalaman tersendiri bagi siswanya agar mereka dapat menghidupkan dari apa yang mereka pelajari dalam konteks akademik maupun kehidupan sehari-hari. Dengannya, pembelajaran Sosiologi dirancang untuk dapat menggugah minat siswa.

Di sinilah kemudian guru-guru Sosiologi perlu merefleksikan kembali pembelajaran sosiologi yang selama ini dikemas dalam setiap pertemuan tatap muka di kelas. Apakah selama ini pembelajaran sosiologi telah memberikan pengalaman yang bermakna bagi siswa sehingga mereka semakin lebih tertarik dengan mata pelajaran ini atau apakah sebaliknya. Guru menjadi tidak hanya dituntut untuk mentransfer ilmu siswa sehingga siswa menjadi paham dengan materi pelajaran yang ada. Tetapi lebih jauh dari itu guru kemudian dituntut secara kreatif untuk dapat menyampaikan materi pelajaran tersebut secara aplikatif dan inspiratif seraya melakukan manajemen kelas. Dalam proses kegiatan Belajar Mengajar guru harus mampu menyajikan berbagai pengalaman belajar yang sesuai dengan karakter anak. Oleh karena itu, guru dituntut mampu mengkombinasikan dan mengkonstruksi model pembelajaran yang telah ada dan diterapkan dalam kelas (Nurkhin dan Wahyudi, 2008).

Menurut Dewey, proses pendidikan harus dilangsungkan dengan berpangkal pada pengalaman anak sendiri. Tidak semua pengalaman itu berfaedah. Oleh karena itu, sekolah harus menjadi tempat yang menyediakan "bahan pelajaran" pengalaman-pengalaman yang berfaedah demi hari depan anak didik dan sekaligus pengalaman itu merupakan hal yang dapat dialami anak didik pada masa sekarang ini (Dewey, 2002:xii). Lebih lanjut, dalam filsafatnya yang dikenal sebagai instrumentalisme, Dewey menekankan pentingnya sistem belajar lewat penga- laman (learning by doing). Betapa pentingnya arti bekerja menurut Dewey, karena bekerja memberikan pengalaman, dan pengalaman menuntun proses berpikir seseorang sehingga orang tersebut dapat bertindak benar dan bijaksana. Pengalaman juga mempengaruhi budi pekerti seseorang. Ada pengalaman positif dan ada pengalaman negatif. Pengalaman positif adalah pengalaman yang benar, pengalaman yang berguna dan dapat diterapkan dalam hidup, sedangkan pengalaman negatif adalah pengalaman yang merugikan atau yang menghambat kehidupan dan tidak perlu dipakai lagi (Dewey 2002:xiii-xiv).

Lalu bagaimanakah perlunya sebuah pengalaman pembelajaran di dalam kelas Sosiologi? Pengalaman-pengalaman seperti apa yang dapat kita berikan pada siswa kita? Pertanyaan itulah yang akan dijawab melalui pemaparan-pemaparan berikut ini.

Salah satu hal yang penting dalam proses pembelajaran mata pelajaran Sosiologi bagi siswa SMA adalah perihal mengaitkan antara topik bahasan dengan pengalaman sehari-hari siswa. Oleh karena itu, penting bagi guru untuk memahami konteks latar belakang siswa-siswinya.

Apabila guru telah memahami konteks latar belakang siswa (keadaan sosial ekonomi, lingkungan keluarga, fasilitas sekolah, dan teman sepergaulan mereka) maka akan mudah untuk menggali berbagai macam kegiatan yang bisa dijadikan sebagai pengalaman belajar siswa. Tentunya, dengan menggali dari apa yang sudah dimiliki oleh siswa akan menjadikan pengalaman itu diolah dan dihayati oleh siswa tersebut, dan bukannya menjadi sebuah pengalaman kosong. Berikut ini adalah beberapa upaya yang penulis coba lakukan dalam memberikan pengalamanpengalaman tertentu pada siswa melalui pembelajaran Sosiologi di kelas.

Vertellen voor de klas adalah bercerita di muka kelas (Mangunwijaya, 2003:66). Hal ini merupakan sarana bagi siswa untuk mengemukakan cerita yang mereka miliki terkait dengan materi yang bersangkutan. Gagasan ini penulis peroleh dari artikel "Biji Unggul dan Tanah Tumbuh" tulisan Mangunwijaya dalam buku Impian dari Yogyakarta.

Suatu hari ketika siswa kelas XI se- 
dang mempelajari masyarakat multikultur, salah satu bagian dari proses belajar mengajar waktu itu adalah melihat beragamnya beberapa kategori masyarakat di Indonesia. Salah satu kategori yang menjadi jembatan bagi siswa untuk bercerita di depan kelas adalah ketika mereka melihat klasifikasi masyarakat Indonesia ditinjau dari segi laju perubahan yang tergolong menjadi masyarakat tradisional dan masyarakat modern. Penulis minta siswa untuk menyimak baik-baik ciriciri masyarakat modern. Setelah itu penulis minta mereka untuk merenungkan dan melihat diri mereka sendiri serta mengkaitkan keberadaan mereka dengan ciri-ciri masyarakat modern tersebut. Penulis minta mereka menceritakan diri mereka apakah mereka modern atau tidak, dengan memberikan bukti atas apa yang mereka ceritakan.

Dalam pikiran penulis, tentunya itu bukanlah hal yang sulit bagi siswa kelas XI untuk bercerita di depan kelas. Akan tetapi kemudian penulis menyadari bahwa ternyata mereka masih perlu berlatih untuk bercerita secara runtut, berani, dan tanpa malu-malu. Oleh karenanya, penulis kemudian memberikan respon yang berbeda untuk tiap-tiap siswa atas apa yang mereka ceritakan di depan kelas.

Vertellen voor de klas terbukti dapat membangun rasa percaya diri siswa. Mereka menceritakan hal-hal yang menjadi kebanggaan mereka. Seperti misalnya ketika Puput menceritakan bahwa dirinya adalah anak yang modern karena ia tidak bergantung pada nasib. Ia menceritakan bahwa ia tidak menggantungkan diri pada uang saku pemberian orang tuanya. Ia menceritakan bahwa untuk membeli kado ulang tahun teman-temannya yang mulai sering dirayakan karena mereka berusia 17 tahun, maka Puput melakukannya dengan cara ia membuat kerajinan tangan yang ia jual kepada teman-temannya. Baginya, hal itu merupakan sebuah hal yang pantas ia banggakan sebagai manusia modern.

Lain halnya dengan Marcella. Cerita yang ia sampaikan di depan kelas adalah cerita yang menunjukkan bahwa ia adalah seorang modern karena memiliki perencanaan. Ia menceritakan bahwa di kelas XI Ilmu So- sial ia sudah memiliki minat studi yang akan ia tempuh di perkuliahan nanti. Perencanaan yang ia lakukan adalah dengan cara membuka situs-situs perguruan tinggi yang memiliki program studi sesuai minat studi yang ia miliki. Dari situ kemudian ia menentukan perencanaan.

Dari dua contoh kecil di atas kita melihat bahwa vertellen voor de klas telah memberikan pengalaman bagi siswa untuk melihat ke dalam diri mereka sendiri. Kemudian mereka secara individual mampu menceritakan keberadaan diri mereka di hadapan temantemannya. Bukankah ini sebuah pengalaman sosial yang menarik, di mana setiap anak harus menepiskan rasa malu mereka dan berinteraksi dengan teman-teman mereka di depan kelas dengan cara bercerita. Kelas akan menjadi hidup karena pengalaman itu dekat dengan kehidupan mereka. Sementara itu, nilai-nilai kehidupan yang ingin diajarkan guru kepada siswa dapat dengan mudah diberikan dengan cara memberi umpan balik dari tiap cerita yang dikemukakan. Apalagi bila kelas terasa dalam atmosfir bahagia atas cerita-cerita lucu dari teman-teman mereka, disitulah pembelajaran nilai-nilai kehidupan yang diberikan oleh guru akan dengan sangat mudah diterima oleh siswa sebab mereka dalam suasana bahagia tertawa.

Pembelajaran vertellen voor de klas juga merupakan bentuk lain dari komponen-komponen pembelajaran Contextual Teaching and Learning yaitu konstruktivisme. Cerita-cerita siswa dari pengungkapan pengalaman kehidupan sosialnya adalah bagian pembelajaran kontekstual. Pembelajaran kontekstual terjadi ketika siswa menerapkan dan mengalami apa yang sedang diajarkan dengan mengacu pada masalah-masalah dunia nyata yang berhubungan dengan peran dan tanggung jawab mereka sebagai anggota keluarga, masyarakat, siswa dan lainnya (Trianto, 2007).

Pengalaman seperti inilah yang sesungguhnya merupakan pembelajaran yang bermakna bagi siswa. Model vertellen voor de klas membantu siswa mengkonstruksikan pengalaman kehidupan kesehariannya di masyarakat dengan mengkaitkan konsep dari materi yang sedang dipelajarinya. Lebih lanjut siswa akan dapat merasakan lebih 
nyata konsep-konsep sosiologi yang dipelajarinya dalam kehidupan sehari-hari, dengan kata lain konsep yang terlihat abstrak menjadi lebih konkrit dipahami oleh siswa. Model pembelajaran vertellen voor de klas dapat dipakai sebagai salah satu cara mendekatkan materi sosiologi dalam diri siswa, dengan menghadirkan kenyataan-kenyataan sosial yang dikonstruksikan oleh siswa sendiri. Proses pembelajaran ini lebih diwarnai dengan proses pembelajaran yang terpusat pada siswa (student centered) daripada berpusat pada guru (teacher centered).

Dalam tulisannya yang berjudul "Comments on the Science of Teaching" dalam buku Anthropological perspectives on education, Goodman mengatakan bahwa:

To learning, the child brings: exploring, questions, aping, taking part, coping, and sociability. "Teachers" can meet the child by answering questions, making the environment fairly safe and copable, making it authentic and relevant to the child's life, providing good personal models, and being sociable (Goodman dalam Wax, Muray L, 1971:118).

Dari situ kita melihat bahwa dalam sebuah pembelajaran, diperlukan pula adanya sebuah daya eksplorasi dengan cara bertanya, sebab dengan demikianlah seorang guru dapat "bertemu" dengan muridnya dalam berbagai keunikan pertanyaan yang diajukan oleh siswa.

Senada dengan hal itu, Mangunwijaya dalam artikelnya yang berjudul "Terima Kasih, Pak Fuad Hassan" dalam buku Impian dari Yogyakarta mengatakan bahwa dalam segala situasi, entah ideal atau tidak, di metropol maupun di pelosok, dalam zaman serba berubah cepat dengan segala simpangsiur norma dan fenomenanya, sang siswa harus begitu dibekali, sehingga ia menjadi manusia yang suka bertanya, yang eksploratif, yang didampingi agar suka ingin tahu, suka mencari, dan mahir merumuskan pertanyaan-pertanyaan. Bukan pertanyaan orang dan pihak lain, tetapi pertanyaan-pertanyaan yang otentik asli hingga dalam hatinya dan yang relevan bagi situasi dia sendiri, (Man- gunwijaya, 2003: 204).

Terdorong oleh pengertian-pengertian itu kemudian penulis memiliki keinginan untuk membiasakan siswa memiliki kemampuan dan kebiasaan untuk mengemukakan pertanyaan kritis dalam pembelajaran Sosiologi. Awalnya, penulis mendapati siswa tampak terasa canggung dan tak biasa untuk mengajukan pertanyaan-pertanyaan kritis. Namun, dengan upaya-upaya tertentu, pada akhirnya mereka mulai terbiasa untuk berani merumuskan dan mengemukakan pertanyaan-pertanyaan mereka sendiri. Upaya itu penulis awali dengan cara menerapkan beberapa taktik. Salah satu taktik yang kemudian penulis pakai adalah dengan memberikan tiket istirahat/ tiket pulang.

Seperti layaknya menonton bioskop maka seseorang akan diperbolehkan masuk apabila dia membawa tiket tersebut. Demikian pula dengan tiket istirahat/ tiket pulang, maka siswa hanya akan diperbolehkan istirahat atau pulang setelah semua anak memberikan tiket itu. Akan tetapi tiket itu tidak berupa kertas kosong semata, melainkan secara verbal ataupun tertulis masing-masing siswa mengemukakan pertanyaannya. Pertanyaan kritis atas apa yang ia renungkan setelah mengikuti pelajaran dengan topik tertentu.

Metode game sangat berpengaruh karena menghibur sekaligus memberikan tantangan. Lee, berpendapat bahwa sebuah game seharusnya tidak dianggap sebagai aktivitas marginal mengisi waktu kosong ketika guru atau kelas tidak punya sesuatu yang lebih baik untuk dilakukan (Windiahsari, 2009). Dalam perjalanannya, di kelas yang penulis ampu, metode mengemukakan pertanyaan kritis sebagai tiket istirahat/ pulang sangatlah efektif diterapkan. Bila penulis berkata lantang "siapa yang mau istirahat?" mereka akan menjawab serentak sambil mengangkat tangan mereka "saya......" Hal tersebut kemudian akan penulis sambung dengan berujar "baiklah, sebagai tiket istirahat, semua anak mengemukakan pertanyaan kritis terlebih dahulu. Penulis beri waktu berpikir lima menit kemudian satu persatu mengemukakan pertanyaannya!"

Tiket pulang atau tiket istirahat den- 
gan mengemukakan pertanyaan kritis sangatlah manjur untuk memancing anak berpikir. Sebab siapakah yang tak ingin segera istirahat atau pulang? Maka pertanyaan-pertanyaan yang membuncah itu akan dijawab. Penulis sebagai gurunya bisa melemparkan pertanyaan untuk dijawab oleh siswa-siswa yang lain. Bahkan, terkadang tak semua pertanyaan bisa dibahas dalam waktu itu juga. Tak mengapa, sebab pertemuan selanjutnya masih ada. Setiap siswa menunjukkan keberadaan mereka dengan pertanyaan yang berbeda-beda. Ada yang sederhana, ada yang kompleks. Hal tersebut membuat mereka memiliki pengalaman untuk merumuskan pertanyaan-pertanyaan.

Setelah mereka terbiasa mengemukakan pertanyaan kritis melalui media tiket istirahat/ pulang, penulis mencoba memodifikasi kemampuan mengajukan pertanyaan kritis tersebut secara berkelompok. Ini adalah taktik kedua yang penulis lakukan untuk membiasakan mereka bertanya secara kritis baik secara individu maupun kelompok. Secara teknis hal ini dilakukan dengan cara membagi siswa secara berkelompok dalam pembahasan sub-sub topik yang berbedabeda. Tiap-tiap kelompok tersebut bertugas untuk mempresentasikan tiap bahan yang berbeda. Karena tiap kelompok memiliki bahan presentasi yang berbeda, maka kelompok yang tidak melakukan presentasi wajib memperhatikan kelompok yang presentasi di depan. Kelompok yang tidak melakukan presentasi wajib mengemukakan pertanyaan kritis pada kelompok yang melakukan presentasi. Sementara kelompok yang melakukan presentasi wajib memberikan jawaban sesuai dengan kemampuan mereka.

Cara tersebut cukup seru dilakukan secara berkelompok, sebab biasanya kelompok pendengar ingin mengemukakan pertanyaan yang berkualitas yang dapat membuat kelompok yang melakukan presentasi berpikir secara kritis pula. Kelompok yang di depan kelas memiliki kepentingan mempertahankan keberadaan kelompok mereka dengan menjawab pertanyaan kritis itu secara kritis pula. Situasi kelas yang hidup menunjukkan mereka menikmati pengalaman tersebut. Terkadang bahkan kelompok pendengar benar-benar mengemukakan pertanyaanpertanyaan yang mendesak sedemikian rupa sehingga mereka merasa bangga. Disitulah paran guru sebagai mediator dimainkan untuk memberikan pengertian-pengertian tertentu kepada murid. Pembelajaran yang demikian ini sungguh merupakan pedagogi tranfromasi. Dimana guru menciptakan situasi belajar yang membuat siswa lebih kritis dan meninggalkan tradisi dengar baca tulis yang secara konvensional membuat pembelajaran berjalan searah.

Salah satu komponen pembelajaran kontekstual, juga menggunakan cara ini, yaitu questioning (bertanya). Konsep ini bertujuan untuk membantu guru mengkaitkan antara meteri yang diajarkannya dengan situasi dunia nyata siswa dan mendorong siswa membuat hubungan antara pengetahuan yang dimilikinya dengan penerapannya dalam kehidupan mereka sehari-hari (Trianto, 2007). Model pembelajaran mengajukan pertanyaan kritis dalam sebuah pembelajaran CTL yang produktif, sebagaimana yang dikatakan oleh Trianto (2007) berguna untuk: 1. Menggali informasi akademik siswa, 2. Mengecek pemahaman siswa, 3. Membangkitkan respon kepada siswa, 4. Mengetahui sejauhmana keingintahuan siswa, 5.Mengetahui hal-hal yang sudah diketahui siswa, 6 . Memfokuskan perhatian siswa pada sesuatu yang dikehendaki guru, 7. Membangkitkan lebih banyak pertanyaan dari siswa, 8 . Menyegarkan kembali pengetahuan siswa.

Sekali lagi, model pembelajaran mengajukan pertanyaan kritis menjadi salah satu cara menyegarkan pembelajaran sosiologi. Dalam pembelajaran ini siswa kembali diajak untuk aktif dan fokus pada arus pertanyaan yang deras mengalir di dalam kelas. Mau tidak mau akan muncul dorongan dalam diri siswa untuk merangkaikan kaa-kata dengan situasi sosial sehari-hari ditambah konsep sosiologi yang telah mereka terima menjadi sebuah pertanyaan kritis yang cukup membanggakan diri siswa. Bentuk inovasi pembelajaran itulah yang menjadikan sosiologi tidak lagi dipandang sebagai mata pelajaran yang membosankan, jauh dari makna kehidupan sehari-hari siswa. Melalui pembelajaran mengajukan pertanyaan kritis konsep- 
konsep sosiologi semakin lebih nyata bagi siswa.

Bagian lain yang penulis coba lakukan dalam rangka memberikan pengalaman pada siswa dalam kelas Sosiologi adalah dengan mengajak mereka bereksplorasi melalui media internet. Hal ini tentunya dapat dilakukan mengingat saat ini masyarakat telah banyak menggunakan media internet untuk menggali informasi. Tujuan kegiatan ini adalah menjadikan eksplorasi sebagai sebuah kesenangan siswa yang menjembatani mereka untuk selalu memiliki rasa ingin tahu.

Dalam sebuah pembelajaran, eksplorasi merupakan hal yang penting. Seperti yang dikatakan Ianni dalam pendapatnya,

\begin{abstract}
And yet, if we consider learning as essentially an exploration of alternatives, and one of the functions of teaching as the economizing of random activity in such choice, then any attempt to encourage such exploration through the art of teaching must take into account the fact that the prospensity to explore is heavily conditioned by the cultural context within which it takes place (Ianni, dalam Wax, M.L., 1971:122).
\end{abstract}

Oleh karenanya, guru harus membuat variasi cara yang dapat diberikan kepada siswa untuk dapat memiliki pengalaman bereksplorasi. Dalam pembelajaran Sosiologi yang penulis lakukan bersama siswa, salah satunya adalah dengan cara eksplorasi gambar/ foto dan eksplorasi artikel terkait dengan tema-tema tertentu dalam pembelajaran. Kegiatan ini dapat dilakukan secara berkelompok sehingga memungkinkan siswa untuk saling berinteraksi dan berdiskusi.

Sebagai contoh, hal ini pernah penulis lakukan dalam pembelajaran dengan topik "Masyarakat Multikultural". Pada bagian ketika murid-murid harus mempelajari faktor-faktor yang menghambat terciptanya masyarakat multikultur, penulis membagi mereka dalam kelompok-kelompok. Setelah itu penulis minta agar tiap-tiap kelompok mencari gambar-gambar dan contoh-contoh kasus terkait dengan beberapa faktor yang menghambat terciptanya masyarakat multi- kultural.

Disitulah nanti ketika siswa telah masuk ke dalam pengalaman eksplorasi, mereka akan menemukan berbagai macam foto yang terkait dengan topik pembelajaran. Foto-foto yang mereka temukan akan meninggalkan kesan tersendiri dalam diri masing-masing murid. Seperti yang dikatakan oleh Ratna dalam tulisannya yang berjudul Mata $\mathrm{Hu}-$ manis Julian bahwa foto menjadi bermakna ketika ia mampu memunculkan relasi bagi yang melihatnya, yang tentunya sangat individual.

Dalam prakteknya, saat siswa menemukan banyak informasi lewat artikel, acapkali mereka tidak mengerti beberapa bagian tertentu sebab informasi itu merupakan hal baru untuk mereka. Di situlah kemudian peran guru akan memberikan pengertian yang lebih dalam atas apa yang sudah diperoleh siswa. Lalu manggut-manggutlah mereka dan sesekali berkata "oooooo". Menarik bukan? Lebih lanjut, penulis dapat melihat bagaimana siswa dalam kelompok masingmasing memiliki kesan terhadap gambargambar yang mereka peroleh dengan cara meminta mereka menceritakan tiap gambar temuan mereka secara berkelompok.

Adapun kemampuan mereka untuk menganalisa artikel-artikel yang ada dinilai dengan cara melihat sejauh mana mereka mampu mengulas artikel tersebut dengan cara menceritakannya kembali, mengaitkannya dengan topik pembelajaran dan lalu mengajukan pertanyaan kritis atas apa yang mereka temukan. Apabila hal tersebut dilakukan secara berkelompok maka terasa hidup pengalaman pembelajaran yang mereka miliki sebab satu orang dapat menambahkan pendapatnya untuk memperkuat pendapat teman mereka dalam satu kelompok.

Dalam perjalanannya, kemampuan anak untuk mengeksplorasi artikel dan gambar/ foto bisa dikembangkan dengan mengajak mereka untuk membuat film secara sederhana lewat media windows movie maker. Hal ini pernah penulisberikan kepada siswa kelas XI Ilmu Sosial ketika mereka mempelajari Masyarakat Multikultural. Mereka memiliki kesempatan untuk membuat film sederhana yang menggambarkan kehi- 
dupan sosial-budaya masyarakat Indonesia dari beberapa suku bangsa.

Mereka mencari gambar-gambar dari internet, lalu mencari dan menganalisis artikel-artikel terkait dengan kebudayaan suku bangsa tersebut. Kemudian mereka mengolahnya sehingga terciptalah film sederhana buatan mereka yang diiringi lagu-lagu daerah hasil pencarian mereka dari internet pula. Sungguh pengalaman yang dimaknai oleh siswa sebagai sesuatu yang menyenangkan. Apalagi bila guru memberikan apresiasi dengan memuji hasil kerja mereka.

Sejalan dengan pembelajaran CTL, eksplorasi merupakan bentuk lain dari proses inkuiri (inquiry). Dalam inkuiri pengetahuan dan keterampilan yang diperoleh siswa diharapkan bukan hasil mengingat seperangkat fakta-fakta, tetapi hasil dari menemukan sendiri. Eksplorasi yang dilakukan penulis dengan mengarahkan siswa menggali informasi melalui gambar/ foto dan artikel melalui media internet merupakan cara yang penulis lakukan untuk siswa menemukan sendiri materi yang diajarkan. Dalam kegiatan eksplorasi ini, siswa telah melakukan kegiatan: 1) observasi (observation), mereka mencari gambar/ foto dan artikel yang sesuai dengan materi; 2) bertanya (questioning), mereka mengajukan pertanyaan kepada diri mereka sendiri, apakah gambar/ foto dan artikel sudah sesuai dengan kebutuhan yang akan mereka analisakan sebagai pengetahuan awal dari materi yang akan mereka pelajari; 3) Mengajukan dugaan (hyphotesis), tahapan bertanya sudah dilakukan, selanjutnya mereka akan melakukan tahapan pembelajaran tuingkat tinggi yaitu mendialektikan dengan mempertanyakan fenomena pada gambar/ foto dan artikel melalui pembuatan hipotesis; 4) Pengumpulan data (data gathering), dilakukan oleh mereka dengan mencari sumber-sumber bacaan yang dapat dijadikan rujukan untuk menjawab hipotesis yang mereka ajukan; 5) Penyimpulan (conclusion), tahap ini dilakukan setelah kegiatan ekplorasi selesai dilakukan, tahap konfirmasi dilakukan secara bersama antara siswa dan penulis sebagai guru.

Salah satu bagian yang paling disukai oleh murid-murid adalah ketika mereka mendapat kesempatan untuk menonton film. Bagian ini digemari oleh mereka karena hal ini membuat mereka merasa lebih rileks. Lewat film, mereka tidak melulu mempelajari topik-topik pelajaran dengan teori-teori yang tersusun di buku paket mereka namun mereka bisa memperkaya pemahaman mereka lewat jalinan cerita yang ada dalam film tersebut. Tentunya, pengalaman menonton film tersebut tidak semata-mata hanya menonton dan dibiarkan berlalu begitu saja.

Seperti yang disampaikan oleh Tjasmadi (2008:44), bahwa fungsi film setidaknya dapat dibedakan menjadi 3 hal, yaitu film sebagai medium ekspresi seni peran, hal ini erat hubungannya dengan seni; film sebagai tontonan yang bersifat dengar-pandang (audio visual), dengan sendirinya berhubungan dengan seni; dan film sebagai piranti menyampaikan pesan apa saja yang bersifat dengar pandang, oleh karenanya film berkaitan erat dengan informasi. Selain itu film merupakan media yang dipakai sebagai saluran (channel) untuk menyampaikan suatu pesan (message) atau informasi dari suatu sumber (resource) kepada penerimanya (receiver) (Yuwono, 2008).

Dalam hal ini, penulis menggunakan pijakan pada fungsi yang ketiga. Hal tersebut kemudian dilakukan dengan cara memberikan beberapa petunjuk yang akan menjadi pedoman bagi siswa untuk menganalisa bagian-bagian mana yang perlu dicermati dalam film yang diputar, untuk kemudian dianalisa dengan menggunakan kerangka pemikiran yang mereka dapatkan lewat topik pembelajaran tertentu. Misalnya ketika penulis mengajak murid-murid kelas XII Ilmu Sosial menonton video dokumenter Unicef untuk Jogja, penulis mengajak mereka untuk melihat tentang beberapa perubahan sosial yang ada.

Setelah film tersebut selesai diputar, penulis meminta mereka untuk mendeskripsikan kembali apa yang mereka lihat lewat film tersebut dalam bentuk surat. Surat itu ditujukan kepada seseorang yang mereka kasihi sehingga penulis dapat menilai sejauh mana kesan yang mereka tuliskan lewat tersebut. Di akhir sesi, setelah mereka selesai menulis surat dan mengumpulkan pada 


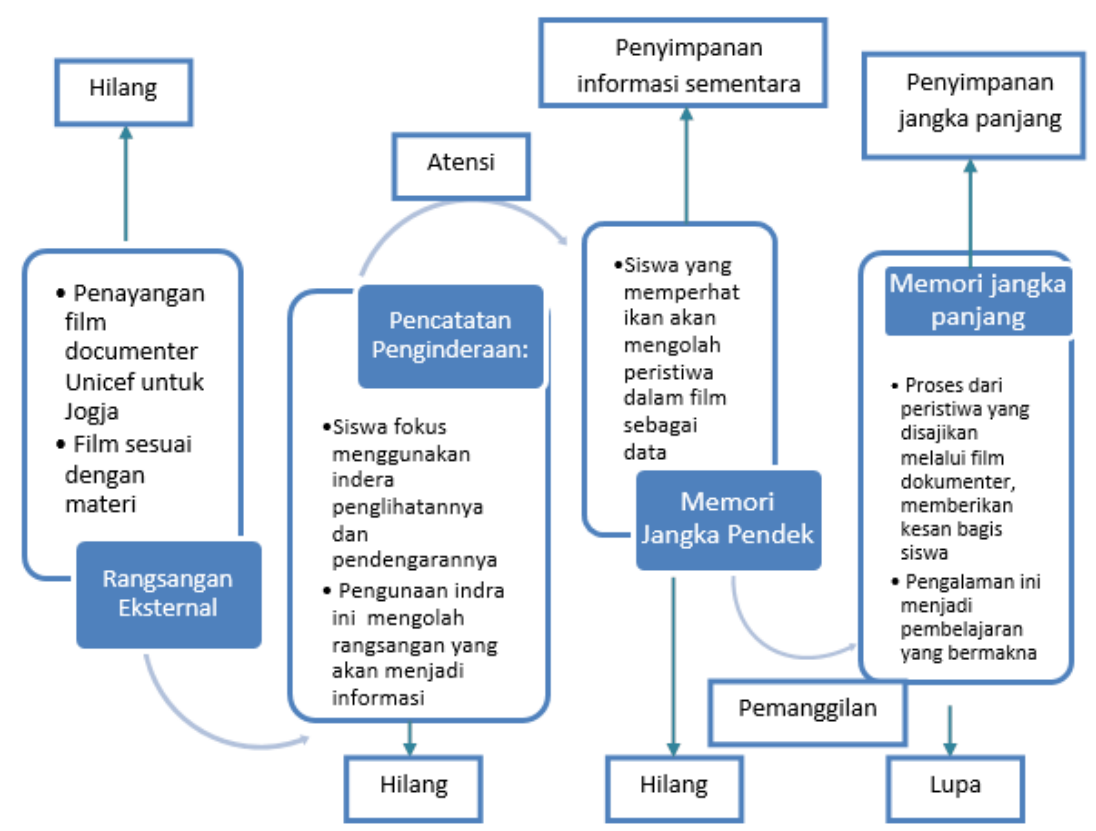

Gambar 1. Pemrosesan informasi dari model pembelajaran berupa nonton film

saya, penulis mengajak mereka untuk diskusi bersama mengemukakan mengapa terjadi perubahan tersebut dan dampak apa yang diakibatkan, serta menganalisa bentuk perubahan tersebut.

Walaupun pembelajaran yang dilakukan penulis terkesan sederhana, namun pembelajaran ini sejalan dengan teori pemrosesan informasi. Teori itu menerangkan alur pemrosesan, penyimpanan dan pemanggilan kembali pengetahuan dari otak (Trianto, 2007). Pemrosesan informasi dari model pembelajaran berupa nonton film dapat dijelaskan melalui Gambar 1 yang diadaptasi dari sistem pemrosesan informasi Arends dalam Trianto (2007).

Salah satu bagian yang dipelajari oleh siswa kelas XII SMA dalam pelajaran sosiologi adalah topik "Penelitian Sosial". Tentunya diperlukan seni tersendiri untuk memberikan pengalaman melakukan penelitian sosial kepada siswa kelas XII yang notabene sedang mempersiapkan segenap daya mereka untuk Ujian Nasional. Akan tetapi hal tersebut dapat disiasati dengan memberikan pengalaman yang tidak terlalu rumit dan berat, dengan pengaturan waktu yang cukup. Misalnya, topik pembelajaran yang lain lebih dimapatkan sehingga mereka punya "ruang" untuk memiliki pengalaman melakukan penelitian sosial sederhana.

Hal tersebut dilakukan secara berkelompok. Siswa dalam kelompok masingmasing menentukan topik yang menarik minat mereka. Kemudian mereka dibimbing tahap demi tahap hingga proses penulisan laporan penelitian. Semua itu tentunya dengan kapasitas mereka sebagai anak Sekolah Menengah, sehingga hasil penelitian mereka tentunya berbeda dengan hasil penelitian mahasiswa perguruan tinggi. Bagian terpenting dalam proses penelitian itu adalah siswa memiliki rasa ingin tahu yang terus dikembangkan, dan memiliki kreativitas. Terlebih lagi, mereka mengalami perjumpaan dengan beberapa fenomena sosial yang akan memberikan kesan tersendiri kepada mereka.

Berikut ini contoh beberapa topik yang pernah diteliti oleh siswa saya, antara lain adalah kuliner Cap Go Meh, Facebook, kesiapan siswa dalam menghadapi Ujian Nasional, Pengemis di Lampu Merah. Hal tersebut sejalan dengan makna pembelajaran cooperative learning. Di mana metode itu merupakan metode yang dilakukan dengan cara siswa dapat bekerja sama satu dengan lainnya untuk memahami isi pelajaran dan bekerja sama secara aktif dalam menyelesai- 
kan tugas (Syafri, 2007).

Mata pelajaran Sosiologi merupakan salah satu bagian dalam ranah mata pelajaran Ilmu Sosial. Tentunya lewat pelajaran Sosiologi ada harapan tersendiri yang dimungkinkan untuk muncul pada tataran anak Sekolah Menengah. Dalam hal ini kita tak dapat memungkiri bahwa mata pelajaran yang lain juga menjadi bagian dari mata pelajaran Sosiologi dalam mencapai harapan yang dimaksudkan. Seperti yang dikatakan Suseno dalam kumpulan esainya, ia menuturkan bahwa mata pelajaran yang lain juga membawa siswa ke pandangan tentang dunia sebagai Mit-welt dan tentang dirinya sendiri sebagai Mit-sein.

Lebih jauh Suseno menjabarkan bahwa kelompok mata pelajaran sosial harus membantu siswa dalam prosesnya untuk menjadi manusia terdidik. Dengan membantu dalam memperoleh pengertian yang lebih sempurna mengenai sosialitas, kelompok mata pelajaran tersebut membantu si anak didik untuk menjadi manusia yang sadar diri sebagai Mit-sein yang bertanggung jawab untuk Mit-dasein (sesama manusia).

Pengertian mengenai hal tersebut memberikan gambaran bagi kita semua bahwa perjalanan pengalaman belajar siswa dalam mata pelajaran Sosiologi dengan berbagai model kreatif inovatif yang diterpakan di atas seharusnya menjadikan pengalamanpengalaman reflektif yang mampu mereka miliki atas semua peristiwa sosial yang dijumpainya. Dalam tataran siswa Sekolah Menengah, penulis yakin itu sudah dapat dilakukan. Oleh karenanya, penulis memiliki harapan bahwa dalam proses belajar-mengajar Sosiologi di kelas akan dapat menjadi jembatan untuk siswa memiliki ketrampilan mengolah rasa lewat kegiatan mengamati dan menulis.

Caranya dapat dilakukan dengan memberikan penugasan kepada siswa untuk membuat catatan harian yang berisi cerita deskriptif dari peristiwa-peristiwa sosial di sekitar mereka. Berawal dari kebiasaan menulis cerita dari perjumpaan-perjumpaan itu, siswa kemudian dibimbing untuk menuliskan refleksi mereka atas perjumpaan itu. Demikian rupa sehingga itu semua akan membawa siswa untuk membangun dunia mereka dalam rangka menyadarkan bahwa diri mereka adalah bagian dari dunia sosial dan berperan untuk memberikan kontribusi sesuai dengan tingkat kedewasaan yang dimiliki.

Hal tersebutlah yang oleh Suseno disebutkan dalam dalilnya bahwa kelompok mata pelajaran sosial membantu manusia muda dalam pertumbuhannya untuk melihat dunianya sebagai Mit-welt dan dirinya sendiri sebagai Mit-sein. Si anak diajak dan dilatih melihat dunia insani sebagai dunia bersama dan dirinya sebagai ada bersama. Melihat dunia sebagai Mit-welt yang seharusnya yaitu Mit-welt dimana manusia harus saling mencintai, adil, saling membantu, dan bergotong royong. Dalam kaitannya dengan siswa, penulis mulai memikirkan untuk mewujudkan harapan melalui pemberian media bagi siswa didik, sehingga mereka memiliki pengalaman reflektif lewat tulisan-tulisan yang mereka buat sendiri.

Berbekal pada pengalaman kemampuan berpikir kritis, eksplorasi dan menikmati film yang sudah mereka miliki, penulis yakin siswa dapat melakukannya. Pada waktunya, mereka akan menjadi manusia-manusia muda yang sudah terlatih untuk menjadi bagian dari dunia dan memberikan kontribusi yang baik, dimulai dari pelajaran Sosiologi di Sekolah Menengah. Kesemuanya merupakan usaha menginternalisasi, membentuk kembali atau membentuk pengetahuan baru, dalam konteks metode pembelajaran inovatif hal itu dikenal sebagai metode yang bersifat kontruktivistik. Keyakinan dalam pembelajaran konstruktivistik adalah "you see what you understand" (Suhardiyanto, 2009).

Bagian-bagian dari model pembelajaran di atas adalah usaha menciptakan seni mengajar yang lebih kreatif inovatif dalam menerapkan komponen-komponen CTL seperti konstruktivisme, bertanya, dan inkuiri. Pengalaman pembelajaran di kelas Sosiologi yang penulis lakukan di kelas setidaknya memberikan contoh yang lebih aplikatif atau operasional dalam penerapan ketiga komponen di atas. Komponen CTL tidak hanya dapat dimaknai sebatas definisi dan konsep semata, namun komponen itu dapat menjadi 
sangat otonom di tangan guru yang kreatif, maka dari situlah lahir beberapa model seni mengajar yang kreatif dan inovatif seperti di atas. Pada akhirnya beberapa hal yang penulis gambarkan di atas mengantarkan siswa secara lebih dekat mencintai mata pelajaran sosiologi, inilah penulis katakana sebagai pembelajaran sosiologi yang menggugah minat siswa.

\section{SIMPULAN}

Mengemas pembelajaran pelajaran Sosiologi di dalam kelas memerlukan suatu upaya tersendiri sehingga siswa dapat memiliki minat terhadap pelajaran Sosiologi. Menumbuhkan minat pada siswa dapat dilakukan dengan memberikan pengalamanpengalaman tertentu pada siswa. Dengan siswa melakukan kerja atas beberapa penugasan itu dapat membuat mereka memiliki pengalaman yang bermakna yang dapat membantu mereka untuk menyadari bahwa mereka adalah bagian dari dunia sosial dan lalu mereka tergugah untuk mulai ikut memberikan kontribusi.

Pengalaman itu dapat diberikan lewat memberikan kesempatan untuk bercerita di muka kelas (Vertellen voor de klas), mengajukan pertanyaan kritis, eksplorasi artikel dan gambar/ foto, nonton film, melakukan penelitian sosial sederhana, dan membuat catatan harian. Pengalaman-pengalaman yang didisain melalui model pembelajaran seperti di atas merupakan format baru yang lebih kreatif dan merangsang siswa untuk masuk dan terlibat secara aktif dalam pembelajaran mata pelajaran sosiologi.

Cara-cara yang ditempuh di atas adalah bagian dari pedagogi transformatif yang lebih operasional dan dapat diterapkan dalam berbagai situasi pembelajaran. Pedagogi transformatif ini lebih menekan pada pendekatan kritis sehingga melalui pembelajaran ini siswa menjadi bagian yang terintegral dalam proses pembelajaran dan kehidupan sosialnya. Pengalaman-pengalaman yang mereka miliki itu diharapkan dapat menggugah minat siswa terhadap pelajaran Sosiologi.

Sesungguhnya apa yang dialami sis- wa dalam kehidupan sosialnya adalah bagian dari yang siswa pelajari dalam konsep sosiologi. Menghadirkan kenyataan atas pengalaman kehidupan sehari-hari melalui pembelajaran kreatif di atas dalah bagian dari memberikan arti bagi siswa untuk menginternalisasikan pembelajaran sosiologi dalam kehidupan mereka. Inilah pembelajaran yang sangat diperlukan agar minat siswa tidak hanya berorientasi pada hasil penilaian di kelas, melainkan sebagai bagian atas kesadaran diri untuk ikut serta memahami dan berkontribusi pada kenyataan kehidupan sosialnya.

\section{DAFTAR PUSTAKA}

Dewey, J. 2002. Pengalaman dan Pendidikan. Yogyakarta: Kepel Press

Goodman, P. 1971. Comments on the Science of Teaching dalam Anthropological Perspective on Education. United States Of America: Basic Books, Inc

Ianni, F. A. J. 1971. The Art on the Science of Teaching dalam Anthropological Perspective on Education. United States Of America: Basic Books, Inc

Mangunwijaya, Y.B. 2003. Biji Unggul dan Tanah Tumbuh dalam Impian dari Yogyakarta. Jakarta: Penerbit Buku Kompas

Nurkhin, A dan Wahyudi, M. 2008. Merancang Pembelajaran Berbasis Multiple Intellegences: Upaya Memahami Keberagaman Kecerdasan Anak. Jurnal Lembaran Ilmu Kependidikan: 37 (2): 143151

Rochana, T. 2010. Keberadaan dan Kendala Pembelajaran Antropologi di SMA. Jurnal Komunitas, 2 (2): $92-99$

Suhardiyanto, A. 2009. Peningkatan Kualitas Pendidikan Melalui Model Pembelajaran Kooperatif Berbasis Konstruktivistik. Jurnal Lembaran Ilmu Pendidikan, 38 (1): 68-77

Syafri, F. 2007. Metode Cooperative Learning sebagai salah satu Alternatif Metode Pembelajaran Membaca dalam Bahasa Inggris. Jurnal Lembaran Ilmu Kependidikan: 36 (2): 124-130

Tjasmadi, J.H.M. 2008. 100 tahun Bioskop di Indonesia. Bandung: Megindo Tunggal Sejahtera.

Trianto. 2007. Model-model Pembelajaran Inovatif Berorientasi Konstruktivistik. Jakarta: Prestasi Pustaka

Yuwono, A. 2009. Pengembangan Kompetensi Menyimak dengan Model CD Pembelajaran Interaktif. Jurnal Lembaran Ilmu Pendidikan. 37(2): $81-90$

Windiahsari. 2009. Penerapan Metode Games dalam Pengajaran Bahasa Inggris Hukum. Jurnal Lembaran Ilmu Pendidikan. 39(2): 162-166 